\title{
Use of Cryptates in Bulk Anionic Polymerization of Styrene
}

\author{
S. RAYNAL \\ Centre de Recherches du Bouchet, Société Nationale \\ des Poudres et Explosifs, 91710 Vert-le-Petit, France
}

(Received February 21, 1983)

\begin{abstract}
The stereoregularity of polystyrene obtained with lithium, sodium, potassium, rubidium, and cesium naphthalenes in the presence of cryptates without solvent was determined by ${ }^{13} \mathrm{C}$ NMR spectroscopy. The effects of cryptates on the polymerization initiated with organolithium compounds were examined. The influence of polymerization temperature and the nature of the cation on the molecular weight, induction period, and stereoregularity of polystyrenes produced were also studied. The polystyrenes obtained were mostly syndiotactic and obeyed the Bernoullian statistics. Finally block copolymerization with isoprene and methyl methacrylate was studied.

KEY WORDS Polystyrene / Bulk Polymerization / NMR / Cryptand / Molecular Weight / Copolymerization /
\end{abstract}

It is well known that in the anionic polymerization of styrene with alkali counterions, tight and loose ion-pairs, and free ions are present in equilibrium depending on the nature of the solvents and temperature. The effects of alkali cation, solvent, and temperature on the rate of polymerization and the stereoregularity of polystyrenes have been investigated in detail. ${ }^{1-19}$ More recently, the NMR spectra of the aromatic $C_{1}$ and methylene carbon were reexamined, and new assignments made based on Bernoullian statistics. ${ }^{16,17}$

In this study I wish to report the effects of cryptated ion-pairs on the stereoregularity of polystyrenes produced in bulk anionic polymerization. The block copolymerization of styrene with isoprene or methyl methacrylate was also studied in the presence of a cryptate. The results were compared with those of solution polymerization of styrene in both the presence and absence of cryptates.

\section{EXPERIMENTAL}

The purification of styrene was described in previous papers. ${ }^{18,19}$ The purification of cryptates and the preparation of $\mathrm{BuLi}, \mathrm{MeLi}, \mathrm{PhLi}$, and alkali naphthalene were outlined in the preceding paper. ${ }^{20}$ Measurement of molecular weights was carried out by GPC using a Waters 200 instrument.
${ }^{13} \mathrm{C}$ NMR spectra $(25.033 \mathrm{MHz})$ were measured on $10-20 \%$ polymer solutions in $o$-dichlorobenzene at $150^{\circ} \mathrm{C}$ with a Brucker spectrometer (model WP 80). The interferograms were accumulated at pulse intervals of 2.1 and $3.5 \mathrm{~s}$. Relative intensities were obtained through the curve resolution assuming a Lorentzian peak shape.

\section{RESULTS AND DISCUSSION}

Variation in Induction Period, Molecular Weight, and Stereoregularity with Polymerization Temperature

It is well known that temperature has only a slight effect on the rate of propagation in anionic polymerization of styrene in tetrahydrofuran. ${ }^{21}$ In a solution, containing cryptates, polymerization is instantaneous and it is difficult to determine the rate of propagation. ${ }^{22,23}$ However in the bulk polymerization of styrene initiated by BuLi with the cryptate [211] it was found that the rates of initiation and propagation are measurable and slower (Figure 1) than in the case of the polymerization in solution. ${ }^{22,23}$ Induction periods are observed as in the case of the polymerization of methyl methacrylate under the same conditions. ${ }^{20}$ Induction periods and the rate of polymerization (Figure 1) are influenced by temperature, but no variation was observed in molecular weight or polydispersity (Table I). 


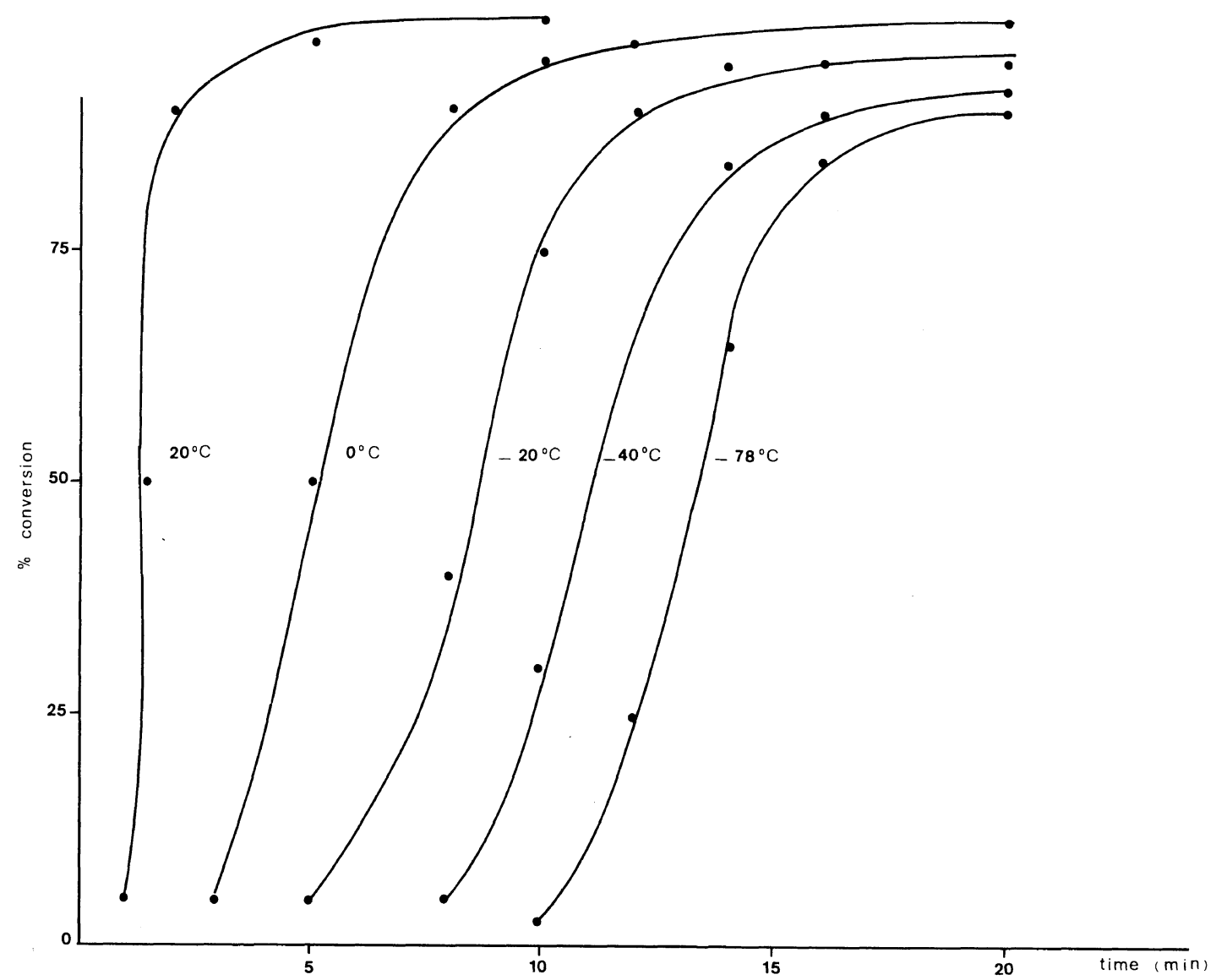

Figure 1. Influence of temperature on the induction period and rate of bulk polymerization BuLi,

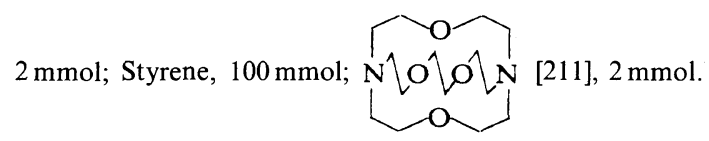

Polystyrenes obtained with cryptates in bulk polymerization are mostly syndiotactic and the stereoregularity of the polymer is almost independent of the temperature (Table II). The presence of cryptated ion-pairs does not affect the configuration (Table II).

Variation in Induction Period, Molecular Weight, and Stereoregularity According to the Nature of the Counterion

The results obtained for the bulk polymerization of styrene initiated by lithium, sodium, potassium, rubidium, and cesium naphthalenes cryptated are summarized in Table III. The nature of the cation had little influence on molecular weight and polydispersity of the polymers produced. In all cases, an induction period was observed which did not vary with the nature of the cation, in contrast to the polymerization of methyl metacrylate and diene monomers under the same conditions. ${ }^{20}$

The polymers obtained were mostly syndiotactic and the proportion of racemic dyads ( 0.59 to $0.67)$ was practically independent of the cation whose properties were lost through complexation (see Table IV). 
Table I. Effect of cryptate [211] on the polymerization systems of styrene/RLi

\begin{tabular}{|c|c|c|c|c|c|}
\hline Initiator $^{\mathrm{a}}$ & $\frac{\text { Temp }}{{ }^{\circ} \mathrm{C}}$ & $\frac{\text { Yield }}{\%}$ & $M_{n}^{\mathrm{b}}$ & $M_{w}{ }^{\mathrm{b}}$ & $M_{w} / M_{n}{ }^{\mathrm{b}}$ \\
\hline BuLi-[211] & -78 & 90 & 125,000 & 372,500 & 3.0 \\
\hline BuLi-[211] & -40 & 92 & 133,000 & 359,000 & 2.7 \\
\hline BuLi-[211] & -20 & 97 & 130,000 & 370,000 & 2.8 \\
\hline BuLi-[211] & 0 & 100 & 140,000 & 387,000 & 2.8 \\
\hline BuLi-[211] & 20 & 100 & 137,000 & 392,500 & 2.9 \\
\hline MeLi-[211] & 20 & 100 & 129,500 & 359,500 & 2.8 \\
\hline $\mathrm{PhLi}-[211]$ & 20 & 100 & 141,000 & 380,300 & 2.7 \\
\hline
\end{tabular}

a $\mathrm{RLi}, 2 \mathrm{mmol}$; styrene, $100 \mathrm{mmol}$; $\mathrm{RLi} /[211]$ molar ratio, 1; polymerization time, $20 \mathrm{~min}$.

b Measured by $\mathrm{GPC}$ at $30^{\circ} \mathrm{C}$ in THF.

Table II. Streoregularity of polystyrenes prepared by $\mathrm{BuLi}$, represented in terms of the triad and racemo dyad fractions

\begin{tabular}{|c|c|c|c|c|c|c|}
\hline Initiator & Solvent & $\frac{\text { Temp }}{{ }^{\circ} \mathrm{C}}$ & $\mathrm{mm}$ & $\mathrm{mr}$ & $\mathrm{rr}$ & $\operatorname{Pr}$ \\
\hline $\mathrm{BuLi}$ & $\mathrm{THF}^{\mathrm{a}}$ & -78 & 0.09 & 0.40 & 0.51 & 0.71 \\
\hline $\mathrm{BuLi}$ & THF & -40 & 0.11 & 0.39 & 0.50 & 0.69 \\
\hline $\mathrm{BuLi}$ & THF & -20 & 0.13 & 0.37 & 0.50 & 0.68 \\
\hline $\mathrm{BuLi}$ & THF & 0 & 0.12 & 0.37 & 0.51 & 0.69 \\
\hline $\mathrm{BuLi}$ & THF & 20 & 0.12 & 0.37 & 0.51 & 0.69 \\
\hline $\mathrm{BuLi}$ & $\mathrm{PhCH}_{3}$ & -78 & 0.14 & 0.40 & 0.46 & 0.66 \\
\hline $\mathrm{BuLi}$ & $\mathrm{PhCH}_{3}$ & -40 & 0.14 & 0.39 & 0.47 & 0.66 \\
\hline $\mathrm{BuLi}$ & $\mathrm{PhCH}_{3}$ & -20 & 0.13 & 0.42 & 0.45 & 0.66 \\
\hline $\mathrm{BuLi}$ & $\mathrm{PhCH}_{3}$ & 0 & 0.10 & 0.40 & 0.50 & 0.70 \\
\hline $\mathrm{BuLi}$ & $\mathrm{PhCH}_{3}$ & 20 & 0.07 & 0.41 & 0.52 & 0.72 \\
\hline BuLi-[211] & $\mathrm{PhCH}_{3}$ & -78 & 0.10 & 0.35 & 0.55 & 0.72 \\
\hline BuLi-[211] & $\mathrm{PhCH}_{3}$ & -40 & 0.11 & 0.37 & 0.52 & 0.70 \\
\hline BuLi-[211] & $\mathrm{PhCH}_{3}$ & -20 & 0.11 & 0.35 & 0.54 & 0.71 \\
\hline BuLi-[211] & $\mathrm{PhCH}_{3}$ & 0 & 0.12 & 0.38 & 0.50 & 0.69 \\
\hline BuLi-[211] & $\mathrm{PhCH}_{3}$ & 20 & 0.11 & 0.37 & 0.52 & 0.70 \\
\hline BuLi-[211] & - & -78 & 0.11 & 0.40 & 0.49 & 0.69 \\
\hline BuLi-[211] & - & -40 & 0.12 & 0.41 & 0.47 & 0.67 \\
\hline BuLi-[211] & - & -20 & 0.12 & 0.42 & 0.46 & 0.67 \\
\hline $\mathrm{BuLi}-[211]$ & - & 0 & 0.12 & 0.44 & 0.44 & 0.66 \\
\hline BuLi-[211] & - & 20 & 0.12 & 0.44 & 0.44 & 0.66 \\
\hline
\end{tabular}

a THF, tetrahydrofuran.

\section{Chain Statistics}

The persistence ratio $(\rho)$ as well as the mean length of the isotactic $\left(\mu_{\mathrm{i}}\right)$ and syndiotactic $\left(\mu_{\mathrm{s}}\right)$ sequences are given in Table $\mathrm{V}$. The persistence ratio defined by Coleman and Fox ${ }^{24,25}$ was close to unity in THF, toluene, and bulk polymerization, indicating that stereoregulation in the polymeri- zation followed Bernoullian statistics. The values of $\mu_{\mathrm{i}}$ and $\mu_{\mathrm{s}}$ indicate the presence of very short isotactic and syndiotactic sequences.

Block Copolymerization with Methyl Methacrylate and Isoprene

Spectroscopic study of the stability of the prop- 
Table III. Effect of cryptates on the polymerization systems of styrene/alkali metal naphthalene

\begin{tabular}{|c|c|c|c|c|}
\hline Initiator $^{\mathrm{a}}$ & $\frac{\text { Yield }}{\%}$ & $M_{n}^{\mathrm{b}}$ & $M_{w}{ }^{\mathrm{b}}$ & $M_{w} / M_{n}^{\mathrm{b}}$ \\
\hline Nap Li-[211] & 90 & 157,500 & 343,000 & 2.2 \\
\hline Nap Na-[221] & 95 & 163,500 & 368,000 & 2.3 \\
\hline Nap K-[222] & 90 & 168,000 & 370,000 & 2.2 \\
\hline Nap Rb-[222] & 100 & 187,500 & 403,000 & 2.1 \\
\hline Nap Cs-[222] & 100 & 210,000 & 407,000 & 2.0 \\
\hline
\end{tabular}

a Alkali metal naphthalene, $2 \mathrm{mmol}$; styrene, $100 \mathrm{mmol}$; alkali naphthalene/cryptate molar ratio $=1$; temperature of polymerization, $0^{\circ} \mathrm{C}$.

b Measured by GPC at $30^{\circ} \mathrm{C}$ in THF.

Table IV. Streoregularity of polystyrenes prepared by alkali metal naphthalene at $0^{\circ} \mathrm{C}$, represented in terms of the triad and racemo dyad fractions

\begin{tabular}{llllll}
\hline \multicolumn{1}{c}{ Initiator } & Solvent & $\mathrm{mm}$ & $\mathrm{mr}$ & $\mathrm{rr}$ & $\mathrm{Pr}$ \\
\hline Nap Li & THF & 0.10 & 0.40 & 0.50 & 0.70 \\
Nap Na & THF & 0.15 & 0.40 & 0.45 & 0.75 \\
Nap K & THF & 0.15 & 0.39 & 0.46 & 0.65 \\
Nap Rb & THF & 0.17 & 0.40 & 0.43 & 0.63 \\
Nap Cs & THF & 0.20 & 0.42 & 0.38 & 0.59 \\
Nap Li-[211] & $\mathrm{PhCH}_{3}$ & 0.12 & 0.38 & 0.50 & 0.69 \\
Nap Na-[221] & $\mathrm{PhCH}_{3}$ & 0.11 & 0.37 & 0.52 & 0.70 \\
Nap K-[222] & $\mathrm{PhCH}_{3}$ & 0.10 & 0.30 & 0.60 & 0.75 \\
Nap Rb-[222] & $\mathrm{PhCH}_{3}$ & 0.15 & 0.29 & 0.56 & 0.71 \\
Nap Cs-[222] & $\mathrm{PhCH}_{3}$ & 0.18 & 0.35 & 0.47 & 0.64 \\
Nap Li-[211] & - & 0.11 & 0.44 & 0.45 & 0.67 \\
Nap Na-[221] & - & 0.12 & 0.47 & 0.41 & 0.64 \\
Nap K-[222] & - & 0.14 & 0.46 & 0.40 & 0.63 \\
Nap Rb-[222] & - & 0.17 & 0.49 & 0.34 & 0.59 \\
Nap Cs-[222] & - & 0.16 & 0.50 & 0.34 & 0.59 \\
\hline
\end{tabular}

agating carbanion end in the polymerization of styrene initiated in the presence of cryptates showed that an absorption at $343 \mathrm{~nm}$ due to the benzylic carbanion, ${ }^{26}$ disappeared very rapidly to give a new absorption at $560 \mathrm{~nm}$ corresponding to the inactive benzyl allyl carbanion. Therefore, it is difficult to obtain block copolymers with cryptated ion pairs in solution.

In bulk polymerization in the presence of the cryptate [211] it seems that deactivation of the carbanion end is slower than in solution under the same conditions and much block copolymers of styrene with methyl methacrylate or isoprene
Table V. Persistence ratio $(\rho)$ and mean length of the isotactic $\left(\mu_{\mathrm{i}}\right)$ and syndiotactic $\left(\mu_{\mathrm{s}}\right)$ sequence of polystyrenes

\begin{tabular}{|c|c|c|c|c|c|}
\hline Initiator & Solvent & $\frac{\text { Temp }}{{ }^{\circ} \mathrm{C}}$ & $\mu_{\mathrm{i}}$ & $\mu_{\mathrm{s}}$ & $\rho$ \\
\hline $\mathrm{BuLi}$ & THF & -78 & 1.45 & 3.55 & 0.97 \\
\hline $\mathrm{BuLi}$ & THF & -40 & 1.56 & 3.56 & 0.92 \\
\hline $\mathrm{BuLi}$ & THF & -20 & 1.70 & 3.70 & 0.86 \\
\hline $\mathrm{BuLi}$ & THF & 0 & 1.65 & 3.76 & 0.87 \\
\hline $\mathrm{BuLi}$ & THF & 20 & 1.65 & 3.76 & 0.87 \\
\hline $\mathrm{BuLi}$ & $\mathrm{PhCH}_{3}$ & -78 & 1.70 & 3.30 & 0.89 \\
\hline $\mathrm{BuLi}$ & $\mathrm{PhCH}_{3}$ & -40 & 1.97 & 3.41 & 0.86 \\
\hline $\mathrm{BuLi}$ & $\mathrm{PhCH}_{3}$ & -20 & 1.62 & 3.14 & 0.94 \\
\hline $\mathrm{BuLi}$ & $\mathrm{PhCH}_{3}$ & 0 & 1.50 & 3.50 & 0.95 \\
\hline $\mathrm{BuLi}$ & $\mathrm{PhCH}_{3}$ & 20 & 1.34 & 3.54 & 1.03 \\
\hline BuLi-[211] & $\mathrm{PhCH}_{3}$ & -78 & 1.57 & 4.14 & 0.88 \\
\hline BuLi-[211] & $\mathrm{PhCH}_{3}$ & -40 & 1.59 & 3.81 & 0.89 \\
\hline $\mathrm{BuLi}-[211]$ & $\mathrm{PhCH}_{3}$ & -20 & 1.63 & 4.08 & 0.86 \\
\hline $\mathrm{BuLi}-[211]$ & $\mathrm{PhCH}_{3}$ & 0 & 1.63 & 3.63 & 0.89 \\
\hline $\mathrm{BuLi}-[211]$ & $\mathrm{PhCH}_{3}$ & 20 & 1.59 & 3.81 & 0.89 \\
\hline $\mathrm{BuLi}-[211]$ & - & -78 & 1.55 & 3.45 & 0.93 \\
\hline $\mathrm{BuLi}-[211]$ & - & -40 & 1.59 & 3.29 & 0.93 \\
\hline $\mathrm{BuLi}-[211]$ & - & -20 & 1.57 & 3.18 & 0.95 \\
\hline BuLi-[211] & - & 0 & 1.55 & 3.00 & 0.98 \\
\hline $\mathrm{BuLi}-[211]$ & - & 20 & 1.55 & 3.00 & 0.98 \\
\hline Nap Li & THF & 0 & 1.50 & 3.25 & 0.97 \\
\hline $\mathrm{Nap} \mathrm{Na}$ & THF & 0 & 1.75 & 3.75 & 0.84 \\
\hline Nap K & THF & 0 & 1.77 & 3.36 & 0.86 \\
\hline Nap $R b$ & THF & 0 & 1.85 & 3.15 & 0.86 \\
\hline Nap Cs & THF & 0 & 1.95 & 2.81 & 0.87 \\
\hline Nap Li-[211] & $\mathrm{PhCH}_{3}$ & 0 & 1.63 & 3.63 & 0.89 \\
\hline $\mathrm{Nap} \mathrm{Na}-[221]$ & $\mathrm{PhCH}_{3}$ & 0 & 1.59 & 3.81 & 0.89 \\
\hline Nap K-[222] & $\mathrm{PhCH}_{3}$ & 0 & 1.66 & 5.00 & 0.80 \\
\hline Nap Rb-[222] & $\mathrm{PhCH}_{3}$ & 0 & 2.03 & 4.86 & 0.70 \\
\hline Nap Cs-[222] & $\mathrm{PhCH}_{3}$ & 0 & 2.02 & 3.69 & 0.76 \\
\hline Nap Li-[211] & - & 0 & 1.50 & 3.05 & 0.99 \\
\hline $\mathrm{Nap} \mathrm{Na}-[221]$ & - & 0 & 1.51 & 2.74 & 1.03 \\
\hline Nap K-[222] & - & 0 & 1.61 & 2.74 & 0.99 \\
\hline Nap Rb-[222] & - & 0 & 1.69 & 2.39 & 1.01 \\
\hline Nap Cs-[222] & - & 0 & 1.64 & 2.36 & 1.03 \\
\hline
\end{tabular}

were obtained. (see Table VI). The difference observed between the theoretical and experimental $M_{n}$ 's was due to an incomplete reaction of the sequence of poly(methyl methacrylate) and polyisoprene. However, it is clear that the polymer chains formed from styrene carry active centers capable of initiating the polymerization of other monomers. 
<smiles>[M]C(=CC(CCC[N+]#[Y10]C(CC(CC)c1ccccc1)c1ccccc1)c1ccccc1)c1ccccc1</smiles>

(benzylic carbanion)

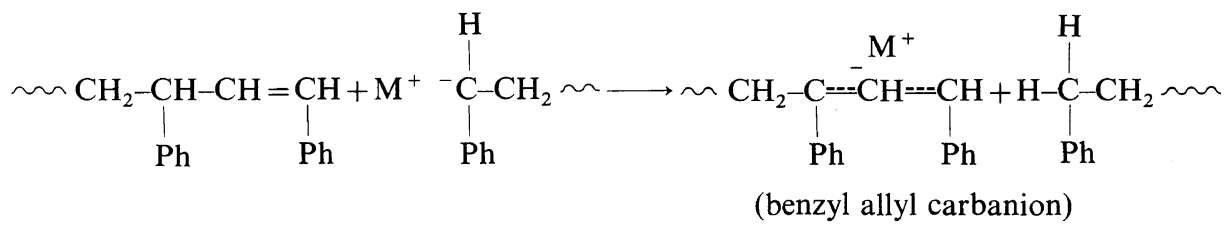

Table VI. Block copolymerization of styrene with methyl methacrylate or isoprene initiated by cryptated $\mathrm{BuLi}$

\begin{tabular}{lccc}
\hline & $\begin{array}{c}M_{n} \\
\text { (theoretical) }\end{array}$ & $\begin{array}{c}M_{n}{ }^{\mathrm{a}} \\
\text { (measured) }\end{array}$ \\
\hline 1 Sequence of polystyrene & 2,500 & 35,000 \\
& $\begin{array}{l}\text { Sequence of poly(methyl } \\
\text { methacrylate) }\end{array}$ & $35,700^{\mathrm{b}}$ & 23,500 \\
& Copolymer & 38,200 & 68,500 \\
2 Sequence of polystyrene & 2,500 & 38,000 \\
Sequence of polyisoprene & $24,600^{\mathrm{b}}$ & 21,300 \\
Copolymer & 27,100 & 59,300 \\
\hline
\end{tabular}

Styrene, $48 \mathrm{mmol}$; methyl methacrylate, $50 \mathrm{mmol}$; isoprene, $47 \mathrm{mmol}$; $\mathrm{BuLi}, 2 \mathrm{mmol}$; [211], $2 \mathrm{mmol}$; temperature of polymerization, $0^{\circ} \mathrm{C}$.

a Measured by GPC at $30^{\circ} \mathrm{C}$ in THF.

b Estimated from the measured $M_{n}$ of the polystyrene sequence.

\section{CONCLUSIONS}

From the present work it was found that the stereoregularity of polystyrenes produced is mostly syndiotactic and is hardly changed by temperature and the nature of the cation. As in the case of bulk polymerization, in the presence of cryptate [211], with methyl methacrylate and diene monomers, the induction period is slightly modified. The possibility of preparing block copolymers should also warrant interest.

\section{REFERENCES}

1. M. Szwarc, "Ions and Ion Pairs in Organic Reactions," Wiley, New York, N. Y., 1974.
2. J. Smid, Angew. Chem. Int. Ed., 11, 112 (1972).

3. D. N. Bhattacharyya, C. Li Lee, J. Smid, and M. Szwarc, J. Phys. Chem., 69, 608 (1965).

4. T. E. Hogen-Esch and J. Smid, J. Am. Chem. Soc., 88, 307 (1966).

5. T. Shimomura, K. H. Tölle, J. Smid, and M. Szwarc, J. Am. Chem. Soc., 89, 796 (1967).

6. L. Lee, R. Adams, J. Jagur-Grodzinski, and M. Szwarc, J. Am. Chem. Soc., 93, 4149 (1971).

7. J. Komiyama, L. L. Böhm, and G. V. Schulz, Makromol. Chem., 148, 297 (1971).

8. B. J. Schmitt and G. V. Schulz, Eur. Polym. J., 11, 119 (1975).

9. K. Matsuzaki, T. Uryu, K. Osada, and T. Kawamura, Macromolecules, 5, 816 (1972).

10. K. Matsuzaki, T. Uryu, T. Seki, K. Osada, and T. Kawamura, Makromol. Chem., 176, 3051 (1975).

11. T. Uryu, T. Seki, T. Kawamura, A. Funamoto, and K. Matsuzaki, J. Polym. Sci., Polym. Chem. Ed., 14, 3035 (1976).

12. M. Szwarc, "Carbanions, Living Polymers, and Electron. Transfer Processes," Interscience, New York, N. Y., 1968.

13. T. Uryu, T. Kawamura, and K. Matsuzaki, J. Polym. Sci., Polym. Chem. Ed., 17, 2019 (1979).

14. T. Kawamura, T. Uryu, and K. Matsuzaki, Makromol. Chem., 180, 2001 (1979).

15. K. Matsuzaki, Y. Shinohara, and T. Kanai, Makromol. Chem., 181, 1923 (1980).

16. S. Suparno, J. Lacoste, S. Raynal, J. F. Regnier, F. Schué, R. Sempere, and J. Sledz, Polym. J., 12, 861 (1980).

17. S. Suparno, J. Lacoste, S. Raynal, J. F. Regnier, F. Schué, R. Sempere, and J. Sledz, Analusis, 9, 155 (1981).

18. S. Suparno, J. Lacoste, S. Raynal, J. Sledz, and F. Schué, Polym. J., 13, 313 (1981).

19. S. Raynal, J. Sledz, S. Suparno, J. Lacoste, and F. Schué, Analusis, 9, 483 (1981).

20. S. Raynal, Polym. J., 15, 1 (1983).

21. F. S. Dainton, D. M. Wiles, and A. N. Wright, $J$. Polym. Sci., 45, 111 (1960). 


\section{S. RAYNAL}

22. S. Boileau, B. Kaempf, S. Raynal, J. Lacoste, and F. Schué, J. Polym. Sci., Polym. Lett. Ed., 12, 211 (1974).

23. J. Lacoste, F. Schué, S. Bywater, and F. Schué, $J$. Polym. Sci., Polym. Lett. Ed., 14, 201 (1976).
24. B. O. Coleman and T. G Fox, J. Polym. Sci., 1, 3183 (1963).

25. B. O. Coleman and T. G Fox, J. Chem. Phys., 5, 1065 (1963).

26. J. Lacoste, Thesis Montpellier (1976). 